\title{
An Evaluation of the Second Intermediate Saudi English Language Textbook from the Teachers' Point of View
}

\author{
Reem BinObaid \\ College of Education, King Saud University, Saudi Arabia \\ E-mail: reeshaah2@gmail.com
}

Doi:10.7575/aiac.alls.v.7n.2p.231

URL: http://dx.doi.org/10.7575/aiac.alls.v.7n.2p.231
Received: $17 / 12 / 2015$

Accepted: 05/02/2016

\begin{abstract}
The study evaluates the quality of the second intermediate grade English language textbook for Saudi girls' schools "from the teachers point of view" which was introduced at the intermediate stage by the Ministry of Education in 2004. This research project evaluates a new textbook that is considered to be the foundation stone in the English language program in Saudi Arabia. A survey questionnaire was used in this study to elicit the perspectives of 50 English language teachers and the population is about 220 teachers in Riyadh Educational Zone about the textbook in question. The questionnaire consisted of 23 items grouped under 5 main categories that are listed as: CB objectives, content, language style, skills, technical aspect and appearance of the CB. The data was subjected to analysis through descriptive statistics. The analysis of the results used several statistical methods which are as follows: Cronbach's alpha, means, percentage, chi square and standard deviations. The findings were generally in favor of the textbook except for the language style and some other sub-items. Out of 23 items in the questionnaire, only 4 items had arithmetic means less than 3.50 (the average). The category that had the highest mean was the one on technical aspects, while the category that had the lowest mean was the one on language style.
\end{abstract}

Keywords: Evaluation, textbook, content, curriculum and syllabus, goals and objectives, materials evaluation

\section{Introduction}

1.1 Background of the Study

The English language is so widely spoken, it has often been referred to as a "world language", the lingua franca of the modern era. Graddol (2000) states that English Language "is the main language of books, newspapers, airports and air traffic control, international business and academic references, science technology, diplomacy, sport, international competitions and advertising". Therefore, since the English language today has become the world language, it is now an international language for communication. As the language has spread, the number of users of English has grown toward a probable two billion Crystal (1985). The spread of the language across cultures, the emergence of varieties of English and the growing differences between them and the communication among people around the world, has become a huge influence on the teaching of the language for both native and non-native speakers. These facts raise the need for an awareness of the status of English today by teachers or anyone concerned about TESOL.

In fact, learning English or any other subject involves three main participants: the teacher, the textbook and the student. Any input provided by the textbook and the teacher, the two main players in this educational process, would not succeed if the third part was unable or unwilling to accept or receive that knowledge.

One of the most important components of curriculum is the textbook which provides a clear framework from which teachers and learners may know where they are going and what is coming next. Ur (2006:184) mentions that "the textbook is the cheapest way of providing learning material for each learner; alternatives, such as kits, sets of photocopied papers or computer software, likely to be more expensive relative to the amount of material provided". Harmer (1991:257) also believes that "textbooks supply attractive, interesting and lively materials which may not be produced by teachers".

"Although the textbook is not the only tool for the teaching and learning process, it is still a significant impact for achieving the language learning objectives. Since teachers find it difficult to develop their own classroom materials, have limited time and lie under external pressure that restricts their ability, it gives more emphasis on the use and utility of the textbook to compensate the loss of authentic materials" \{cited in Almazloum and Qeshta (2009:2)\}. From this point the author focuses on the importance of textbook evaluation, (Ansary and Babaii, 2002) state that "evaluation process covers different fields of the curriculum; mostly the content represented by the textbook".

However, looking at the Saudi Arabian context, one can notice that the country is in transition socially, economically and politically. Because of this, the role that teaching English plays in Saudi Arabia may be ambiguous for many Saudis or it may be that the learners have a clear idea of why they are studying English but course designers do not. This implies that in order to keep up with the quick rate of changes in Saudi Arabia, evaluations of Saudi textbooks should 
be a priority for teaching English in schools. It is obvious that in Saudi Arabia, learning English occurs as part of the normal school curriculum. Typically, English is learned either to pass exams as a necessary part of one's education or for career progression while working for an organization or business with an international focus. Regarding for curricula in Saudi Arabia, there are several research results such as Thinker (2000) and Al-Zuhairi (2008) indicating that the achievement of Saudi students in English is low and one of the most important causes of this is the textbooks taught in intermediate and secondary schools.

As teachers who are concerned about the learning situation noticed that the English curriculum in Saudi schools has difficulties for both teachers and learners, going from this point we consider the importance of evaluation of Saudi English textbook. In this study the author evaluates the Second Grade Intermediate English Course Book in Saudi Arabia from teachers' point of view, "Say It in English", which was implemented in 2005 by the Ministry of Education in Riyadh. This teachers' evaluation is significant because it reveals the strengths and weaknesses of the text book, determines how well the textbook meets the standards of a good textbook and provides guidance and feedback for the chosen textbook.

This study sheds light on the teachers and their effect on evaluation of the English textbook because they are the most important element in achieving learning. Jolly and Bolitho (1998), cited in Li (2004) remark that "teachers understand their own learners best because they understand their needs and their preferred learning styles" (pp. 18-19). Students are also well positioned to know their own learning styles and their curricular needs. The main reason for embarking on this type of study lies in the fact that the contents of English textbooks have a significant association with the learning of the students. The content of English textbook must not contain errors because these errors once imbibed by the student as the correct ones will have adverse effects on his/her learning. The study will be concluded by the author's view toward teachers' evaluations via text book from the author's experience in teaching English at Saudi schools.

\subsection{Problem Statement}

Teaching the English curriculum "Say It In English" for second intermediate grade has been taught in Saudi Arabia since (2003-2004). Therefore, the author has taught this CB for ten years and it was noticed that many teachers complained numerous problems in dealing with this textbook. Some of them believed that this textbook is beyond students' level. Furthermore, the researcher noticed that many students were not able to use the language properly and this may be due to the nature of the textbook. That is why the author in this study evaluates the selected CB from teachers' point of view to investigate the strengths and weaknesses of this $\mathrm{CB}$ to come up with suggestions and recommendations that can be beneficial in developing the selected CB. Accordingly, the author hopes that the result of this study will help in future studies and researches which are interested in the same field.

\subsection{Purpose of the Study}

Since 2003-2004, the Saudi English Second Grade Intermediate CB has not been formally evaluated. Therefore, it was worthwhile to carry out this evaluation. For teachers, while predictive evaluation precedes the implementation of a CB, a retrospective evaluation examines materials that have actually been used. Al-Saif (2005) maintained that while textbooks are central to how EFL teaching is done in Saudi Arabia, there is much need for an evaluation of their content and to investigate the role of teachers in teaching practice and methodology.

Material evaluation aims:

$>$ Identify the strengths in the Second Intermediate Saudi English Language Textbook from the teachers' point of view in CB objectives, content, language style, skills, technical aspect and appearance of the CB.

$>$ Identify the weaknesses in the Second Intermediate Saudi English Language Textbook from the teachers' point of view in $\mathrm{CB}$ objectives, content, language style, skills, technical aspect and appearance of the CB.

\subsection{Theoretical Framework}

Teaching English as a Foreign Language in Saudi Arabia:

In 1927, the first primary and secondary schools were established in Saudi Arabia. In the same year, both English and French languages were introduced at the secondary level, but with no specific syllabus. In 1953, the intermediate level was introduced and a specific syllabus for teaching English was established for both intermediate and secondary levels $\{$ Al-Subahi (1988)\}. This syllabus was imported from Egypt, but did not go with some Saudi learners' customs and needs. In addition, other factors such as the poverty of the country and the high levels of illiteracy contributed to the slow progress in learning $\{$ Al-Sadan $(2000)\}$.

\subsubsection{The Educational Policy of Saudi Arabia}

The conference sponsored by the government of Saudi Arabia in 1958 marked a new era in the history of educational organization in the country as regional educational offices were established for the first time to supervise education in their local districts. In 1970, the basis of educational policy was established in order to help students to learn in a correct and comprehensive manner. Four stages for the educational system in Saudi Arabia were established by the Ministry of Education: kindergarten, primary, intermediate and secondary. The students usually start their education at the age of six and spend six years in the primary stage and three years each for the intermediate and secondary stages Khafaji (2004). The purpose of education involves that the Islamic belief is planted and spread, and that students are raised with Muslim values, teachings and ideals. The students are equipped with skills and knowledge which allow them to contribute beneficially to the development of Saudi Arabian society economically, socially and culturally, having been fully prepared to become a useful member in the building of his community (Ministry of Education, 1970, Article 28). 
The importance of the implication of learning English in Saudi schools is obvious in the Minister of Education's address to the English language teachers written in Arabic on the second page of all elementary, intermediate and secondary course books. Teachers are encouraged to do the following: to prepare the students to use English, which has become one of the most widely used languages in the world, for the continuation of the Muslims' role in human civilization through gaining knowledge in arts and science written in this language. This can be done without promoting morals and customs which are contradictory to our religious beliefs (Ministry of Education, General Directorate of Curricula, 2002).

The general objectives of teaching English in Saudi Arabia according to the new curriculum document published in 2001 are:

Students should be able to:

$>$ develop their intellectual, personal and professional abilities.

$>$ acquire basic language skills in order to communicate with English language speakers.

$>$ acquire the linguistic competence necessarily required in various life situations.

$>$ acquire the linguistic competence required in different professions.

$>$ develop their awareness in communicating using English.

$>$ develop positive attitudes towards learning English.

$>$ develop the linguistic competence that enables them to be aware of the cultural, economic and social issues of their society in order to contribute in giving solutions.

$>$ develop the linguistic competence that enables them, in the future, to present and explain the Islamic concepts and issues and participate in spreading Islam.

$>$ develop the linguistic competence that enables them, in the future, to present the culture and civilization of their nation.

$>$ benefit from English speaking nations, in order to enhance the concepts of international cooperation that develop understanding and respect of cultural differences among nations.

$>$ acquire the linguistic bases that enable them to participate in transferring the scientific and technological advances of other nations to their nation.

$>$ develop the linguistic basis that enables them to present and explain the Islamic concepts and issues and participate in the dissemination of them \{Al-Hajailan (2005)\}.

The objectives listed above aim to enhance the understanding of English-speaking cultures and bridge these cultures with the Islamic culture of Saudi Arabia. In addition,

they aim to equip Saudi students with the English skills they might need for academic and commercial purposes.

1.4.3 The Curriculum of Teaching English at Saudi Schools

Al-Hajailan (2005) states "English was taught at the elementary stage from 1348 to $1361 \mathrm{H}$ and was stopped for undeclared reasons"(p. 2). In 2004, English was introduced to the elementary stage again but to sixth grade only. The number of periods was reduced to two periods a week, while English is being taught four times a week at intermediate stages.

The general objectives of teaching English language for the second intermediate stage that the author is going to evaluate in this study, as stated in the student's book, are listed below. The pupils should be able to:

- Repeat some phrases and sentences in English which are useful to understand and absorb the content.

- Read and write simple sentences and numbers in English.

- Spell some of the words and use punctuation properly.

- Configure a list of words and phrases.

- Recognize some of the rules of the English language and the correct usage. At the end of the year, students will be able to :

- Greet people and produce themselves.

- Provide knowledge of family and friends.

- Talk about family and relatives.

- Talk about school.

- Question and give information.

- Give a description of someone.

- Ask someone on the phone.

- Question about the price of something.

- Be able to write simple sentences about self, family, friendship, and place of residence.

And appreciate the importance of English language as an international language of communication for introducing Islam. Furthermore, appreciate the importance of the English language as an international language of communication to benefit from the achievements of other cultures in accordance with Islam (Al-Mofarreh, et al, 2005, p. A).

\subsubsection{Materials Evaluation}

Materials evaluation is the systematic appraisal of the value of materials in relation to their objectives and to the objectives of the learners using them. Evaluation can be pre-use and therefore focused on predictions of potential value. 
It can be whilst-use and therefore focused on awareness and description of what the learners are actually doing whilst the materials are being used. And it can be post-use and therefore focused on analysis of what happened as a result of using the materials" $\{$ Tomlinson $(1998$, p. xi) $\}$.

\subsubsection{Defining Materials Evaluation}

The term evaluation has been defined as a variety of processes in the field of applied linguistics. Lynch (1996) defines evaluation as "the systematic attempt to gather information in order to make judgments or decisions" (p. 2). As for materials evaluation as a field of study, Carter and Nunan define it as "the process of measuring the value of learning materials". This can be predictive pre-use evaluation, ongoing whilst-use evaluation or retrospective post-use evaluation (p. 223). Harmer (2001) stated a distinction between evaluation and assessment. He confirmed that "the assessment of a course book is an out-of-class judgment as to how well a new book will perform in class. Course book evaluation, on the other hand, is a judgment on how well a book has performed in fact" (p. 301). In addition to text materials McGrath (2002) contends that "materials could include regalia: real objects such as a pencil, a chair or a bag and representations such as a drawing, a photograph of a person, house or scene" (p. 7) .

\subsubsection{The importance of Materials evaluation}

There is abundance of academic literature on the design, selection, adoption and evaluation of English language textbooks. Some have maintained that the design of the material should be primarily informed by L2 acquisition and teaching theory, while others have maintained the imperatives of implementing socio-culturally sensitive designs as would embrace and utilize pre-existing L1 linguistic characteristics and experiences. Through a review of selections from recent scholarships on the topic raised, contemporary pedagogical debates and academic opinions on the issues of L2 textbook design, selection, adoption and evaluation shall be presented. Bruder (1978) suggests the use of a checklist of eight criteria: level, objectives, style, language, age, time, convictions and competency. He claims that these criteria should be considered from the viewpoints of teachers and students. Williams (1983) argues for the design and application of a more systemic evaluative approach.

Recognizing that the inherently complex nature of L2 teaching material evaluation has spawned various evaluation paradigms, Williams (1983) believes that the design and implementation of a single, comprehensive assessment framework would allow for both more consistent evaluation standards and impose optimal design criteria upon textbook designers. He proposes an evaluative scheme which assesses the effectiveness of the material from pedagogical, linguistic, general and technical perspectives. Textbooks should, therefore, be evaluated on their inclusion of general linguistic instructions and rules, their simplified presentation of linguistic techniques, such as grammatical and syntactical rules, their embrace of practice material, as in reading passages, which both teach language, as in vocabulary and grammar, and can function to guide students' writing skills and, lastly, on their provision of phonetics guides \{Williams (1983)\}.

Cunningsworth (1984) discussed the principles and criteria for course analysis. The criteria he recommended are discussed under the following headings: language content, selection and gradation of language items, presentation and practice of new language items, developing language skills and communicative abilities, supporting materials motivation and the learner, conclusions and overall evaluation. At the end of his book, he provided a checklist that should be used in course evaluation.

Tu'eimah (1985) planned three different tools: a tool for language teaching textbook evaluation, a tool for language teaching textbook analysis, and a tool for measuring language teaching textbook readability. The analysis tool consists of fifteen categories. These are the book's physical make up, the nature of the course, pre-preparation studies, the language of the book, method of teaching, language skills, grammar, vocabulary, linguistic drills, assessment and evaluation, cultural content, aids and activities, individualized learning, the teacher's manual and others. The evaluation tool consists of eight categories: pre-preparation studies, language content, language skills, methods of teaching, drills and evaluation, aids, physical make up, and overall impression. Finally, Tu'eimah (1985) suggests the use of cloze tests for measuring readability. He provides an example of how to use cloze tests in order to measure the readability of language teaching textbooks.

\subsection{Context of the Study}

According to information technician center in the Ministry of education "2014", the number of female intermediate schools in Riyadh is 210 school, and 664 female intermediate English teachers in all regions in Riyadh which means there are about 223 second intermediate English teachers.

The study sample consisted of fifty (50) English language female teachers of the English textbook "Say it in English" for second intermediate grade in Riyadh who were asked to answer the questionnaire carefully prepared by the researcher and it was distributed among female English teachers at intermediate schools for all different regions in Riyadh for evaluation purposes. This sample was selected randomly.

The study population consists of female teachers of English textbook "Say It In English" scheduled for the second intermediate grade in the Kingdom of Saudi Arabia. To achieve the objectives of the study, the researcher is going to prepare a questionnaire to assess the dimensions of the English text book of the second intermediate grade in SA. 
This study might:

1. Help the curriculum planners and designers to reveal the points of strength of "Say It In English" to be reinforced and the points of weakness to be avoided and treated in the future.

2. Help the administrators at the Ministry of Education to develop new textbooks that satisfy the students' needs.

3. Help teachers to address deficiencies in this textbook through the proposed supplementary activities.

\subsection{Research Questions}

- What are the strengths in the Second Intermediate Saudi English language textbook in CB objectives, content, language style, skills and technical aspects and appearance of the CB from the teachers' point of view?

- What are the weaknesses in the Second Intermediate Saudi English language textbook in CB objectives, content, language style, skills and technical aspect and appearance of the CB from the teachers' point of view?

\subsection{Limitations}

- $\quad$ This study was concerned only with evaluating the Saudi Second Grade Intermediate English CB, "Say It In English", which was implemented in 2005 from teachers' points of view.

- This study has a limited number of participants who are female English teachers of second intermediate grade in Riyadh.

- English second grade intermediate teachers from different regions in Riyadh are participating in answering the questionnaire in this study.

\section{Literature Review}

Textbooks have a significant role in the process of innovation. According to Hutchinson and Torres(1994), the significance of the textbook evaluation becomes more vivid in periods of change. Besides being a fundamental teaching tool in regular English teaching and learning contexts, textbooks may act as go-betweens and possible agents for change during educational innovation because of many reasons. Firstly, textbooks act as a tool for teacher and learner training, secondly, textbooks provide a picture of how the renewal will look and lastly, they provide the psychological support to instructors.

Besides, evaluation of the English language curriculum has become very crucial in all EFL contexts. This has coincided with the efforts of the educational authorities to produce native-like speakers of English in places where English is not the native language. The Kingdom of Saudi Arabia has always been engaged in improving the English language teaching programs at all levels for several years. Therefore, this study is an attempt to enhance these efforts by evaluating "Say It In English" the textbook for second intermediate grade based on input from teachers.

So in the literature review it will be presented several topics related to material evaluation. The theoretical literature review "syllabus evaluation rationale" investigated the studies contributing to the theory of textbook evaluation, while the Syllabus Evaluation in the Global Context and in the Saudi context literature review, introduced a summary of research studies on EFL textbook evaluation, with greater emphasis on those studies that evaluated Saudi English CBs. The literature on theoretical studies reviewed some evaluation criteria and checklists developed by various researchers and writers to check the suitability of English language textbooks. This review guided the construction of the overall skeleton of this study: the research questions, the Textbook Evaluation Tool (TET), the procedures of analysis, etc. In addition, types of material evaluation were presented (predictive evaluation, summative evaluation, retrospective evaluation, etc.). In light of reviewed literature, it is evident that $\mathrm{CB}$ evaluation is necessary if proper materials are introduced and better methods are followed.

\subsection{Reasons for Textbook Evaluation}

The evaluation of textbooks seeks to identify any weaknesses and strengths of textbooks and helping in the selection process of a textbook with the scope to minimize the negative effects and maximize the positive ones. Textbook evaluation, according to Cunningsworth (1995), would involve the careful selection of materials examining whether they reflect the needs of the learners, the aims, methods and values of a specific teaching program. Textbook evaluation helps the teachers move beyond impressionistic assessments and it further facilitates them to acquire useful, accurate, systematic and contextual insights into the overall nature of textbook materials \{Cunningsworth(1995) and Ellis(1997)\}. Through the evaluation of a textbook, teachers know the content of the book, its strengths and weaknesses which will help them to adapt it to suit the course aims, learners' needs and teachers' beliefs. As Littlejohn (1998) observes, textbook evaluation serves the purpose of examining whether the methodology and content of the materials are appropriate for a particular language teaching context. The evaluation would test out the claims materials make for themselves: whether they truly develop autonomy, whether they truly involve problem solving and if they indeed are learner centered.

\subsection{Types of Syllabus Evaluation}

Rod Ellis (1997) differentiates between two types of materials evaluation: a predictive evaluation and a retrospective evaluation. A predictive evaluation is designed to construct a decision regarding what materials to use, while a retrospective evaluation is designed to examine materials that have actually been used. It also serves "as a means of testing the validity of a predictive evaluation, and may point to ways in which the predictive instruments can be improved for future use" \{Ellis (1997, p. 37)\}. He argues that instructors often run into the mission of selecting the 
materials that they will use. In other words, the teachers need to accomplish a predicative evaluation of the materials that they have in hand in order to decide which materials suit their purposes the best. Moreover, just the once they use these materials, they require to carry out further evaluation to identify whether these materials were workable or not. This is what is called the retrospective evaluation $\{$ Ellis (1997: 36)\}.

Rea-Dickens(1994) cited in Li(2004) summarizes three kinds of evaluation: (1) per-use evaluation which can be done prior to the use of a $\mathrm{CB}$ for the purpose of checking the construct validity and the match with needs; (2) in-use evaluation; and (3) post-use evaluation, measured in terms of learners' performance. She advocates giving more attention to in-use and post-use evaluation.

Other studies claim that the notion that curriculum reform is a very complex exercise \{Fullan and Miles(1992),Anderson(1995) and Gamoran(1997)\} connected to all aspects of teaching and learning curriculum reforms have important benefits, but they must occur in concert with other social changes to have a significant and long lasting effect. Klein (1994) argues that reforms constantly fail to reach the desired outcomes because they neglect the social issues that surround each school or district.

Taba-Tyler (1962) cited in Pierson and Friederichs (1980) argues that a CB evaluation determines the extent to which the curriculum objectives are met. Low (1989) cited in $\operatorname{Kim}(2001$, p.136) claims that teaching materials are "one of the major determinants of what (is) taught in language teaching programmes". Al-Hajailan (1999) explains that while formative evaluation is carried out during the implementation process, summative evaluation can only be conducted at the end of the process. Sharp (1990, p.133) argues that although classical evaluation procedures may work well, there is an inherent dependence on the "course/ program objectives being or having been clearly stated", regardless of whether or not they were achieved. Sharp calls for the use of an "illuminative evaluation" of courses where there is less concern with prediction and measurements and more concern with description and interpretation.

Nevertheless, this paper is a kind of the retrospective evaluation. A retrospective evaluation provides teachers with information regarding the strengths and weaknesses of the used syllabus as it is in this study, since the textbooks in Saudi public schools are not produced by the EFL instructors themselves.

\subsection{Syllabus Evaluation Rationale}

Since the textbook is regarded as the observable spirit of any English language teaching program. It is the foundation for how much linguistic input the students will get in the classroom \{O'Neill (2008)\}. Richards (2011) argues that in some contexts, textbooks may supply the ground for the content of the lessons, and the type of linguistic practice the learners engage in. In other contexts, textbooks may be matching to the teacher's instruction. For students, textbooks may be the core source of contact they have with the language apart from input given by the instructor (Cowling (2007) $\}$. Furthermore, textbooks may serve as a kind of training to the teachers by giving them ideas on how to teach lessons.

Williams (1983) suggests a material evaluation scheme which accounts for language teaching assumptions as well as the linguistic and the pedagogical components associated with these assumptions. The assumptions on which the scheme is based are: (1) An up-to date methodology of second language teaching, (2) Needs of learners, (3) Guidance for non-native speakers of English, and (4) Relevance to socio-cultural environment. He proposes an EFL/ESL textbook evaluation questionnaire, which includes 7 criteria in 28 categories: general, speech, grammar, vocabulary, reading, writing and technical. While the first criteria, general, "embrace global considerations of methodology, the needs of the learner, the teacher and the community" \{Williams (1983, p. 352)\}, the technical criteria are concerned with "the quality of editing and publishing; the availability of supplementary material; cost and durability of the text; authenticity of language and style of the writer, etc." (pp. 352-353). Williams maintains that such a checklist is not exhaustive and teachers "can evolve their own sets of criteria for different educational levels or language teaching situations" (p. 353). $\mathrm{He}$ also argues that the validity of certain criteria can be certified by seeking the judgments of other teachers or linguists.

Fillmore's; Andrade (1990) proposed guidelines for evaluating ESL basic textbooks for adults. The proposed 50-item checklist is divided into the following categories: adult appeal, individual differences, motivation and attitudes, educational background, social context, presentation/practice, and linguistic/social/ discourse/strategic competence. Many scholars offer checklists based on generalizable criteria. These detailed checklists use a variety of methods to assess how well a particular textbook measures up to certain standards. Farr and Tulley cited in Chambliss (1994) reviewed 70 checklists of English Language Textbooks and found that the number of criteria on the checklists ranged from 42 to 180 items.

Skierso (1991) suggests a different framework for textbook analysis. She explains that the first step of material evaluation is to collect information about students' background, the course syllabus, and the learning context. Skierso then divides materials into five subsections: bibliographical data, aims and goals, subject matter, vocabulary and structures, and layout and physical makeup. Cunningsworth (1995) presents a checklist of evaluation criteria for English as a Second or Foreign Language (ESL/EFL) teaching material. The category of language content addresses how language form, language functions, and patterns of communicative interaction are organized. Garinger (2001) echoes Hartley's (1992) claims that three content areas need to be addressed when evaluating a textbook's content: teaching objectives, depth and breadth of material, and whether the textbook needs to be supplemented or not. This is consistent with the evaluation criteria suggested by Cunningsworth (1995). 
Ranalli (2002) evaluated the New Headway Upper-Intermediate course book (CB) according to Cunningsworth's (1995) four general guidelines, with particular emphasis on the syllabus and methodology used. The guidelines are as follows:

(1) course books should correspond to learners' needs;

(2) course books should reflect the uses (present and future) which learners will make of the language;

(3) course books should take account of students' needs as learners and should facilitate their learning processes, without dogmatically imposing a rigid method; and

(4) course books should have a clear role as a support for learning.

$\mathrm{Xu}(2004)$ developed a predictive textbook evaluation questionnaire which is based on a sufficient number of practice activities that fit all parts of the learning process, many activities on a similar theme or topic, follow-up questions for all readings, contemporariness of the curricular content, activities which promote communication, and activities that meet the needs of multi-level classes. Stein and others (2001) argue that material evaluation should include not only screening criteria, but also a comprehensive content analysis, such as content organization; the presence of explicit, generalizable strategies; opportunities for scaffolded instruction; the strategic integration of skills and concepts; and judicious review.

\subsection{Syllabus Evaluation in the Global Context}

Mehrdad (2012) evaluated the general English course at Islamic Azad University of Hamedan, Iran. The examiner used a questionnaire to study the students' conceptions of good learning of English expressed in terms of their own wants and lacks. The findings of the study emphasized on the students' improving according to the course syllabus in different ways. The mass of the students expressed their need to increase their vocabulary and strengthen their grammar.

In addition, Zarei \& Khalessi (2011) investigated cultural density in the internationally distributed textbooks (IDTs) of English Language, i.e., Interchange Series. The results of the study showed that textbooks are artifacts which are strongly focused in cultural assumptions and biases.

Kontozi (2010) conducted a study "Analysis and Evaluation of English 6th Grade textbook used in Greek public Schools". The study investigated the suitability of the textbook used for 6th Grade primary EFL learners of Greek state schools. The results of the study suggested that the strengths of the book could be identified in areas of organization, thematic content and inclusion of all the language skills. However, the problematic areas related to authentic language, integration of skills, nature of tasks and materials for assessment.

Furthermore, Thein (2006) conducted a study to evaluate the appropriateness and effectiveness of the textbooks used for teaching English to religious studies students at Myanmar Institute of Technology. He collected data by using questionnaires, interviews, and classroom observations from teachers and learners. The study explored the degree to which teachers and learners' outlook counterpart the objectives of the program in developing students' communicative skills and critical thinking. The results discovered that textbooks used in the program were not suitable for reasons including: the textbooks did not provide to attain the needs and wants of both teachers and learners, they were not efficient to support students' critical thinking and they were not efficient in developing the students' communicative skills for everyday life situations. Thein (2006) suggested that textbooks must be localized to meet teachers and learners' needs. He also emphasized upon the importance of adapting activities that encourage collaborative learning, natural and empirical interactions to help young people think critically.

Kirkgöz (2009) evaluated three English textbooks (Texture, Time for English, and Trip 1) taught to grade four classes in primary schools under the Turkish Ministry of National Education. For this purpose, he planned the questionnaire based on the curriculum objectives and the guidelines given by other researchers. The findings of the study revealed that students generally settled that each textbook was colorful, explained via using pictures with interesting characters, drawings, and were appropriate to their own level. All of these factors facilitate learning of English and create entertaining. Teachers also stated that the books encourage student-centered learning helping them to take an active part in the learning progression through a diversity of activities.

\subsection{Syllabus Evaluation in the Saudi Context}

The author shedding light on some Saudi researchers are the most knowledgeable about the societies in which they live. They evaluate Saudi textbooks according to students' level and students' needs in their own culture and society.

Al-Hajailan (2003) echoes Jarvis and Adams' (1979; p.53) remarks that curriculum evaluation "involves all the components related to curriculum", i.e. educational objectives, the content, the teaching strategies, and the evaluation techniques. He also states that materials should be analyzed descriptively before starting the evaluation process.

Al-Saif (2005) conducted a comprehensive evaluation of the textbook English for Saudi Arabia which is taught in the 6th grade in Saudi elementary schools. The purpose of the study is to examine the strengths and the weaknesses of the textbook with particular emphasis on its suitability to teachers, social contexts and young learners. He uses quantitative study. The sample of the study consisted of 144 male and 149 female English teachers, supervisors and trainers who participated in training elementary stage English teachers. The questionnaires contained 93 specific criteria in 12 categories: rationales, objectives, language skills, teaching aids, vocabulary, grammar, content, methodology, the Workbook, the Teacher's Manual, assessment techniques and general aspects of the textbook. With regard to teachers' opinions, the results of the study showed that the delivery of data was not conclusive. It determined that the textbook 
was only "moderately adequate" and that it required constant and cyclical evaluation based on the changing circumstances of the program. Al-Saif (2005) argues that this finding "suggests some indecisiveness on the part of the evaluators" (p. 62), caused by their limited training and their experience of the textbook. This shows that besides the level of curriculum implementation, teacher professional development is a major factor in any successful textbook evaluation.

Madkhali (2005) proposes an alternate syllabus design for the one currently taught at the Institute of Public Administration (IPA) in Riyadh, Saudi Arabia. The objectives for this new design are based on the findings of needs analyses at two settings: English for Academic Purposes (EAP) at the IPA, and English for job purposes at the Saudi private sector department (PSD). Madkhali uses multi-modal approach to data collection that includes questionnaires, four focus groups: (IPA alumni, IPA English language teachers, and teachers-students in the PSD), and interviews with different populations: students, managers, employees, etc. The researcher uses descriptive statistics and t-test to analyze the quantitative data, and content analysis for the interpretation of the qualitative data. Using a 5-Likert scale questionnaire, the results show that EAP students face difficulties in three English language skills: reading, writing and speaking. Similarly, the perceptions of PSD students were that to a certain degree they face difficulties in the four language skills. Based on the needs found, the researcher advises teaching two business courses: Business Correspondence and Business Communication. In addition, the researcher proposes an alternate design for the current program at the IPA's English Language Center which should focus on General English, rather than English for Specific Purposes.

Alamri (2008) evaluated quality of a sixth grade English language textbook for Saudi boys' schools which was introduced at elementary stage by the Ministry of Education in 2004. This research project evaluates a new textbook that is measured as the basic part in the English language program in Saudi Arabia. A survey questionnaire was used in this study to draw the perspectives of 93 English language teachers and 11 supervisors in the Riyadh Educational Zone about the textbook in question. Findings focus on some of the teaching methods and some other sub-items. The results also discovered that although the criteria such as general appearance, design and illustration, topic suitability, skills development and flexibility are satisfied by the book but still they need to be improved.

Khafaji (2004) evaluated the materials used to teach English to the secondary level in Saudi public high schools. He discussed general educational policy of the Kingdom and a specific policy for teaching English. The outcomes of this study concluded that the materials have failed to supply students with a sufficient source of motivating and academically purposeful material to achieve the aims and objectives set for the students' learning process. The study also exposed that the Audio-Lingual approach, which is the fundamental approach in teaching the materials, has been a factor in preventing the capabilities of accomplishing aims and objectives of learning the language.

Al-Sowat (2012) "Evaluation of an English book (Say it in English) scheduled for first grade average in Saudi Arabia, designed to evaluate English book for first grade average from the teachers' point of view in the province of Taif. The study also examined the statistical differences between the views of teachers depending on the "type, years of experience and the interaction between gender and years of experience." The outcomes showed that the degree calendar English book for first grade average was good for three criteria evaluation and weak for six evaluation criteria and in general, the evaluation degree of public books was weak. Many activities and supplementary materials were invented to support the book such as audio-visual materials and tests, and language laboratories and stories. The results also showed that there were statistically major differences between the views of teachers in favor of the return parameters to their types. Also, it showed that there were no statistically significant differences between the views of participants in the research that are due to experience or to the interaction between experience and kind.

Habtoor (2012) conducted a study to evaluate First Class: English for Tourism, as an English for Specific Purposes (ESP) textbook taught to the sophomore students of Tourism and Archaeology at King Saud University, Riyadh, Saudi Arabia. The study revealed the opinions of the teachers on the textbook regarding its components, its practicality, its activities, the language type, the subject, the content, the four major language skills, the sub-skills of grammar and vocabulary and how they are offered. It also investigated the suitability of the book regarding the learners' level and their needs. The results revealed that the textbook matches the teachers' expectations about their students' progression in learning in the Saudi Arabian context. In addition the results showed that there was a harmony among the teachers on the suitability of the textbook.

Al-Yousef (2007) evaluated the third grade intermediate English Course Book in Saudi Arabia implemented in 2005 by the Ministry of Education. His study conducted with a total sample of 184: 96 male and female teachers and supervisors in Saudi Arabia, as well as 88 male students who were using the 2005 English CB. The study revealed that the teachers, supervisors and the students evaluated the course book as moderately adequate. Both the quantitative and the qualitative findings have shown that the content and the visuals of the textbook were among the categories that gained the most support, while gradation and recycling and supplementary material were the most poorly rated categories.

Al-Jaser (1989) compared boys' and girls' First Secondary-level English Textbooks. He reported that such textbooks should be customized in the light of students' gender, level, and needs. Ereksoussy (1993) conducted an evaluation of the girls' First Grade Intermediate English textbook. She evaluated the objectives, the content selection, practice activities and assessment models. 
From my experience as an English teacher for all the grades at Saudis schools:

$\checkmark$ There are many factors affecting the evaluation of English CBs which are: content, teaching methods, appropriateness to the learners' level, learner's needs, learners' proficiency, learners' differences, learners' environment and learners' culture. That is why the author mentioned some Saudi studies for evaluation English text books at Saudi schools.

$\checkmark$ The author believes that the teacher is the anchor stone in the learning process. Of course, we cannot ignore the learner and the way he studies the textbook but the teacher plays a great role in evaluation and sometimes in designing English textbook. The author thinks that the emphasis should be on the importance of teachers in understanding and catering to the students' needs, interests and abilities. The rationale behind the methodology is that students will be more engaged and enthusiastic about the curriculum if it is adjusted to their preferences.

$\checkmark$ This study agrees with most of the studies in that " those who are responsible for evaluation are teachers" , while other studies focus on some other elements such as supervisors or students. That is why the questionnaire is distributed among teachers.

The author agrees with the scholars in the importance of evaluation of the CB but what is new with this study is to evaluate the selected CB from teachers' point of view.

\section{Research Methodology}

This chapter focuses on the research methodology, principle approaches to research methodology, the participants of the study, data gathering, data analysis and the research procedure. It also provides the structure of the questionnaire and ways of text analysis.

\subsection{Research Design}

This study aimed at evaluating the second intermediate grade English language course book for Saudi girls' schools "Say It In English", which was published in 2005 by the Ministry of Education, Riyadh, Saudi Arabia. The term CB was used here to refer (inclusively) to the Pupil's Book, the Workbook, the Supplementary Material and the Teacher's Manual of the series. Materials evaluation has an important value for the development and administration of languagelearning programmes" $\{$ (McGrath, 2001, p. 1)\}.

One of the main reasons for materials evaluation according to Cunningsworth (1995) is "to identify particular strengths and weaknesses in course books already in use, so that optimum use can be made of their strong points, whilst their weaker areas can be strengthened through adoption or by substituting materials from other books" (p. 14). For the reasons above, a survey of this study was conducted to elicit the views of a representative number of English language teachers in the Riyadh Educational Zone about the second intermediate grade English textbook for Saudi schools. The research is concentrated on answering the following research questions:

- What are the strengths in the Intermediate Saudi English language text book in CB objectives, content, language style, skills and technical aspects and appearance of the CB from the teachers' point of view?

- What are the weaknesses in the Intermediate Saudi English language text book in CB objectives, content, language style, skills and technical aspect and appearance of the CB from the teachers' point of view?

\subsection{Setting}

This study is a descriptive quantitative study, which seeks to evaluate the English textbook of second intermediate grade "Say It In English" in the Kingdom of Saudi Arabia from teachers' point of view to cover the purpose of the study. The research took place in most of the intermediate girls' schools in Riyadh via distributing a questionnaire randomly to evaluate second intermediate English course book " Say It In English " from the teachers' point of view.

\subsection{Participants}

According to the technical information center in the Ministry of Education "2014", the number of female intermediate schools in Riyadh is 210 school, and 664 female intermediate English teachers in all regions in Riyadh, that's mean 220 second Intermediate teachers in Riyadh. The study sample " participants" consists of (50) English language female teachers for second intermediate grade in Riyadh to answer a questionnaire carefully prepared by the researcher which is distributed among female English teachers at intermediate schools for all different regions in Riyadh , to evaluate second intermediate English textbooks according to the teachers' opinions. This sample has been selected randomly.

\subsection{Procedure}

The survey "questionnaire" will be distributed among second intermediate English teachers at Riyadh intermediate schools. This questionnaire consists of five dimensions which are: objectives, content, language style, skills and technical aspect of the course book. Also, each dimension has multiple statements. The total of 23 statements will be answered by second intermediate teachers in Riyadh. The data will be collected and analyzed to evaluate the second intermediate English course book from teachers' point of view.

\subsection{Data Collection}

To achieve the objectives of the study, the researcher prepared a questionnaire to assess the dimensions of the English text book of second intermediate grade in SA. The teachers' responses to the questionnaire statements were collected and analyzed in terms of frequency and percentage of responses. The researcher used the program Statistical Package 
for Social Sciences, version 16.0 (SPSS) in the analysis of the results which used several statistical methods which are as follows: Cronbach's alpha, mean, percentage, chi-square and standard deviations. The SPSS was used to analyze the quantitative data collected for this study. The data were initially entered into an excel spreadsheet using variable labels and values and including each participant. Each participant was assigned a unique identification number for anonymity. The excel file was imported into SPSS and a master data file was built. This master data file was stripped of all participants to ensure the confidentiality of each participant.

\subsection{Reliability of the Study Tool and Validity}

\subsubsection{Validity of Experts}

It is the general appearance or the external image of the test in terms of vocabulary, how to formulate it and the extent of its clarity. Also, it indicates how valid it is and the appropriateness of the test for its purpose. The questionnaire which was used in this study will be presented to experts "specialists" in the Department of Curriculum Faculties of Education at King Saud University and Princess Noura University in order to identify the extent to which the questionnaire is affiliated to its dimensions, clarity and suitability to its purpose. They will also be asked to edit, delete and increase as necessary.

\subsubsection{The Stability of the Tool}

The stability of the questionnaire will be calculated using Cronbach's alpha to measure reliability of the study. The author distributed the questionnaire among a small sample of "8 English teachers" from second intermediate Saudi schools in Riyadh to examine how valid is the tool. Generally speaking, a strong reliability coefficient ranges from about 0.65 to 0.95 . Alpha coefficients of 0.70 or higher were considered acceptable $\{$ DeVellis (1991)\}. The results show that Cronbach's alpha is 0,83 . Therefore, the questionnaire is valid to be applied on the sample of the study.

\section{Results and Discussion}

\subsection{The Results of Data Analysis}

Focused main objective of this study to determine:

1. What are the strengths in the Intermediate Saudi English language text book in CB objectives, content, language style, skills and technical aspects and appearance of the CB from the teachers' point of view?

2. What are the weaknesses in the Intermediate Saudi English language text book in CB objectives, content, language style, skills and technical aspect and appearance of the CB from the teachers' point of view?

To achieve the goals of the study an approval scale was designed according to the five grades as follows:

1. Number (5) refers to: Strongly agree.

2. Number (4) refers to: Agree.

3. Number (3) refers to: Neither agree nor disagree.

4. Number (2) refers to: Disagree.

5. Number (1) refers to: Strongly disagree.

To determine the level of assessment of the study, sample items in the questionnaire were considered as follows:

- $\quad$ The Mean (Greater than 1.00 but less than 1.80) : Strongly disagree(S.D.)

- $\quad$ The Mean (Greater than 1.80 but less than 2.60) : Disagree(D.A)

- The Mean (Greater than 2.60 but less than 3.40): Neither agree nor disagree $(\mathrm{N})$.

- $\quad$ The Mean (Greater than 3.40 but less than 4.20: Agree (A).

- $\quad$ The Mean (Greater than 4.20 but less than 5.00: Strongly agree (S.A).

\subsection{Statistical Treatments}

To answer the questions of the study, the researcher entered the data to SPSS (Statistical Package for Social Sciences), then makes the necessary statistical analysis. Also, the researcher calculated as arithmetic averages(mean), standard deviations, frequencies and percentages for each item, uses Chi - square and determines the degree of approval for each item of the scale categorized as follows : (Strongly agree, agree, Neither agree nor disagree, Disagree, or Strongly disagree.

\subsection{The Results of Items of the Questionnaire and the Study Questions}

The researcher calculates frequencies, percentages, averages, standard deviations, estimates, chi-square and ranks to study sample responses.

Table No. (1) shows the values of the frequencies ,percentages, averages, standard deviations, estimates, chi - square and ranks responses of study sample items: Objectives. 


\begin{tabular}{|c|c|c|c|c|c|c|c|c|c|c|c|c|c|}
\hline \multirow[t]{2}{*}{ \# } & \multirow[t]{2}{*}{ Paragraphs } & & \multicolumn{5}{|c|}{ Responses } & \multirow[t]{2}{*}{ Means } & \multirow[t]{2}{*}{ Std. } & \multirow{2}{*}{$\begin{array}{c}\text { Chi - } \\
\text { Square }\end{array}$} & \multirow[t]{2}{*}{ Sig. } & \multirow[t]{2}{*}{ Rate } & \multirow[t]{2}{*}{ Rank } \\
\hline & & & $\begin{array}{l}\text { Strongly } \\
\text { disagree }\end{array}$ & Disagree & $\begin{array}{l}\text { Neither } \\
\text { agree nor } \\
\text { disagree }\end{array}$ & Agree & $\begin{array}{l}\text { Strongly } \\
\text { agree }\end{array}$ & & & & & & \\
\hline \multirow[t]{2}{*}{1} & \multirow{2}{*}{$\begin{array}{l}\text { Textbook } \\
\text { objectives } \\
\text { are clear and } \\
\text { accurate to } \\
\text { be applied. }\end{array}$} & $\mathrm{F}$ & - & 4 & 7 & 30 & 9 & \multirow[t]{2}{*}{3.88} & \multirow[t]{2}{*}{0.80} & \multirow[t]{2}{*}{33.68} & \multirow[t]{2}{*}{$0.0^{*}$} & \multirow[t]{2}{*}{ A } & \multirow[t]{2}{*}{2} \\
\hline & & $\%$ & - & 8.0 & 14.0 & 60.0 & 18.0 & & & & & & \\
\hline \multirow[t]{2}{*}{2} & \multirow{2}{*}{$\begin{array}{l}\text { Objectives } \\
\text { are realistic. }\end{array}$} & $\mathrm{F}$ & - & 3 & 6 & 34 & 7 & \multirow[t]{2}{*}{3.90} & \multirow[t]{2}{*}{0.71} & \multirow[t]{2}{*}{50.0} & \multirow[t]{2}{*}{$0.0^{*}$} & \multirow[t]{2}{*}{ A } & \multirow[t]{2}{*}{1} \\
\hline & & $\%$ & - & 6.0 & 12.0 & 68.0 & 14.0 & & & & & & \\
\hline \multirow[t]{2}{*}{3} & \multirow{2}{*}{$\begin{array}{l}\text { Objectives of } \\
\text { the material } \\
\text { are suitable } \\
\text { for students' } \\
\text { level. }\end{array}$} & $\mathrm{F}$ & - & 10 & 7 & 25 & 8 & \multirow[t]{2}{*}{3.62} & \multirow[t]{2}{*}{0.99} & \multirow[t]{2}{*}{17.0} & \multirow[t]{2}{*}{$0.001 *$} & \multirow[t]{2}{*}{$\mathrm{A}$} & \multirow[t]{2}{*}{3} \\
\hline & & $\%$ & - & 20.0 & 14.0 & 50.0 & 16.0 & & & & & & \\
\hline \multirow[t]{2}{*}{4} & \multirow[b]{2}{*}{$\begin{array}{l}\text { Objectives } \\
\text { can be } \\
\text { achieved } \\
\text { within the } \\
\text { specific time } \\
\text { that has been } \\
\text { limited. }\end{array}$} & $\mathrm{F}$ & - & 15 & 7 & 21 & 7 & \multirow[t]{2}{*}{3.40} & \multirow[t]{2}{*}{1.07} & 11.12 & $0.01 *$ & A & 4 \\
\hline & & $\%$ & - & 30.0 & 14.0 & 42.0 & 14.0 & & & & & & \\
\hline
\end{tabular}

* Means statistically significant at the level of significance $(0.05=\alpha)$.

Notes from the results table (1) earlier mentioned that the values of Means of the items of the first branch ranged between (3.40 - 3.90), while the values of standard deviations ranged between (0.59 - 1.07).

Notes from the results presented by the table (1) that all the chi - square values for all the items have been statistically significant at the level of $(\alpha=0.05)$. Which illustrates the contrast the views of the members of the study sample on these items. This means that the true observation does not correspond with the expected observation.

The following order of the items of the first branch arranged from high to low, as follows:

1. The first rank of item (2), which states: I Objectives are realistic, with mean (3.90), standard deviation (0.71), and agree of appreciation.

2. The second rank of item (1), which states: Textbook objectives are clear and accurate to be applied, with mean (3.88), standard deviation (0.80), and agree of appreciation.

3. The third rank of item (3), which states: Objectives of the material are suitable for students' level, with mean (3.62), standard deviation (0.99), and agree of appreciation.

4. The fourth rank of item (4), which states: Objectives can be achieved within the specific time that has been limited, with mean (3.40), standard deviation (1.07), and agree of appreciation.

The means for Overall performance (3.70) with a standard deviation (0.89), and agree of appreciation.

Table No. (2) shows the values of the frequencies ,percentages, averages, standard deviations, estimates and ranks responses of study sample items: Content.

Table 2. Student responses to paragraphs related to the field: Content

\begin{tabular}{|c|c|c|c|c|c|c|c|c|c|c|c|c|c|}
\hline \multirow[t]{2}{*}{ \# } & \multirow[t]{2}{*}{ Paragraphs } & & \multicolumn{5}{|c|}{ Responses } & \multirow[t]{2}{*}{ Means } & \multirow[t]{2}{*}{ Std. } & \multirow{2}{*}{$\begin{array}{c}\text { Chi - } \\
\text { Square }\end{array}$} & \multirow[t]{2}{*}{ Sig. } & \multirow[t]{2}{*}{ Rate } & \multirow[t]{2}{*}{ Rank } \\
\hline & & & $\begin{array}{l}\text { Strongly } \\
\text { disagree }\end{array}$ & Disagree & $\begin{array}{l}\text { Neither } \\
\text { agree } \\
\text { nor } \\
\text { disagree }\end{array}$ & Agree & $\begin{array}{c}\text { Strongly } \\
\text { agree }\end{array}$ & & & & & & \\
\hline \multirow[t]{2}{*}{1} & \multirow[b]{2}{*}{$\begin{array}{l}\text { The content } \\
\text { of the book is } \\
\text { appropriate } \\
\text { with the } \\
\text { principles of } \\
\text { Islam and our } \\
\text { culture. }\end{array}$} & $\mathrm{F}$ & - & 3 & 4 & 25 & 18 & 4.16 & 0.82 & 27.92 & $0.0^{*}$ & $\mathrm{~A}$ & 1 \\
\hline & & $\%$ & - & 6.0 & 8.0 & 50.0 & 36.0 & & & & & & \\
\hline
\end{tabular}




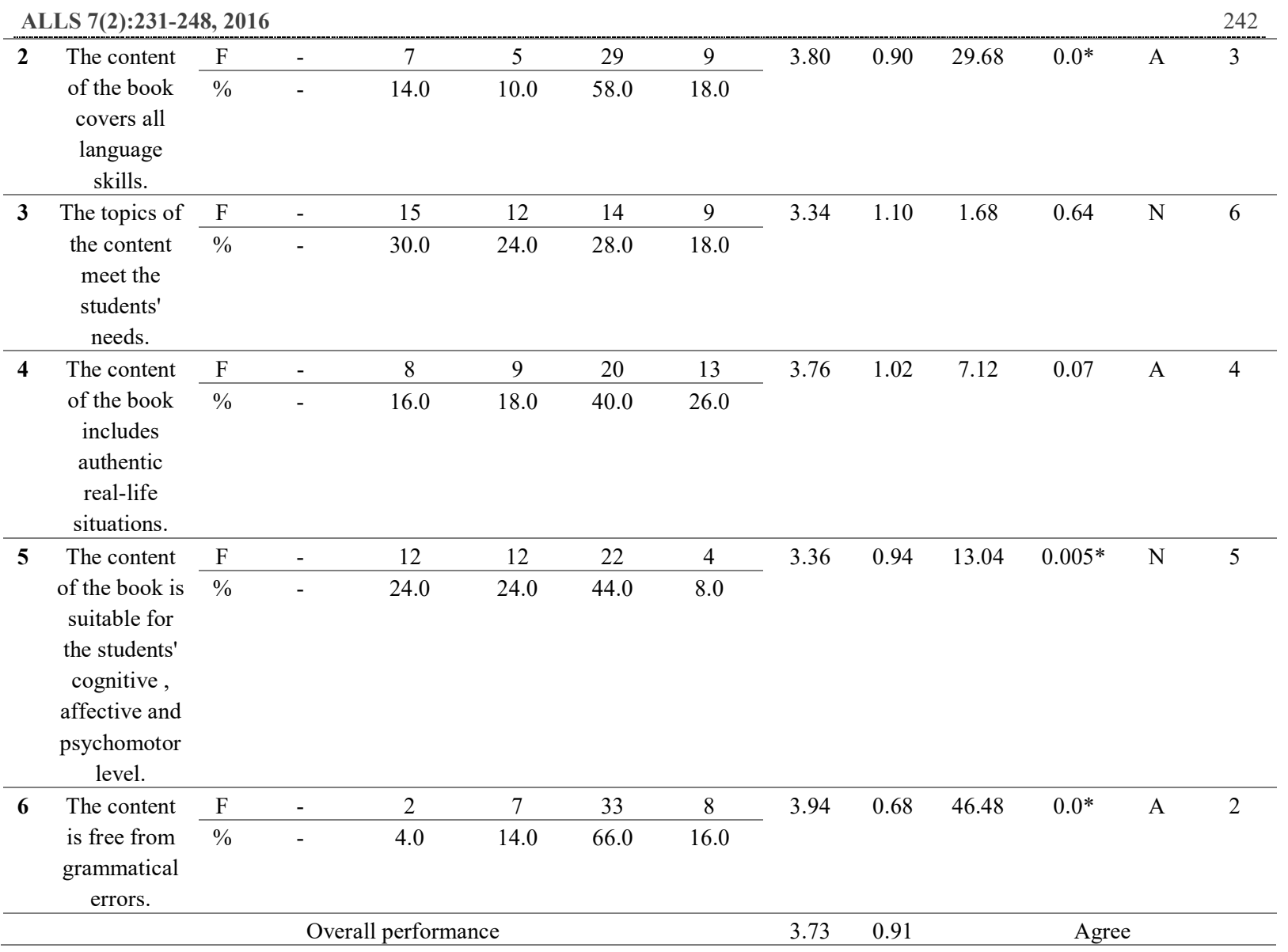

* Means statistically significant at the level of significance $(0.05=\alpha)$.

Notes from the results table (2) earlier mentioned that the values of Means of the items of the second branch ranged between $(3.34$ - 4.16), while the values of standard deviations ranged between $(0.68-1.10)$.

Notes from the results presented by the table (2) that the chi - square values for the items $(1,2,5$, and 6$)$ have been statistically significant at the level of $(\alpha=0.05)$. Which illustrates the contrast the views of the members of the study sample on these items. This means that the true observation does not correspond with the expected observation, but the chi - square values for the items (3and 4) have not been statistically significant at the level of $(\alpha=0.05)$.

The following order of the items of the second branch arranged from high to low, as follows:

1. The first rank of item (1), which states: The content of the book is appropriate with the principles of Islam and our culture, with mean (4.16), standard deviation (0.82), and agree of appreciation.

2. The second rank of item (6), which states: The content is free from grammatical errors, with mean (3.94), standard deviation (0.68), and agree of appreciation.

3. The third rank of item (2), which states: The content of the book covers all language skills, with mean (3.80), standard deviation (0.90), and agree of appreciation.

4. The fourth rank of item (4), which states: The content of the book includes authentic real-life situations, with mean (3.76), standard deviation (1.02), and agree of appreciation.

5. The fifth rank of item (5), which states: The content of the book is suitable for the students' cognitive, affective and psychomotor level, with mean (3.36), standard deviation (0.94), and neutral of appreciation.

6. The sixth rank of item (3), which states: The topics of the content meet the students' needs, with mean (3.34), standard deviation (1.10), and neutral of appreciation.

The means for Overall performance (3.74) with a standard deviation (0.91), and agree of appreciation.

Table No. (3) shows the values of the frequencies ,percentages, averages, standard deviations, estimates and ranks responses of study sample items: Language Style. 
Table 3. Student responses to paragraphs related to the field: Language Style

\begin{tabular}{|c|c|c|c|c|c|c|c|c|c|c|c|c|c|}
\hline \multirow[t]{2}{*}{$\#$} & \multirow[t]{2}{*}{ Paragraphs } & & \multicolumn{5}{|c|}{ Responses } & \multirow{2}{*}{$\begin{array}{c}\text { Mean } \\
\mathrm{s}\end{array}$} & \multirow[t]{2}{*}{ Std. } & \multirow{2}{*}{$\begin{array}{l}\text { Chi - } \\
\text { Squar } \\
\text { e }\end{array}$} & \multirow[t]{2}{*}{ Sig. } & \multirow[t]{2}{*}{ Rate } & \multirow{2}{*}{$\begin{array}{c}\text { Ran } \\
\mathbf{k}\end{array}$} \\
\hline & & & $\begin{array}{l}\text { Strongly } \\
\text { disagree }\end{array}$ & Disagree & $\begin{array}{l}\text { Neither agree } \\
\text { nor disagree }\end{array}$ & Agree & $\begin{array}{c}\text { Strongly } \\
\text { agree }\end{array}$ & & & & & & \\
\hline \multirow[t]{2}{*}{1} & \multirow{2}{*}{$\begin{array}{l}\text { The language used } \\
\text { in the text book is } \\
\text { realistic. }\end{array}$} & $\mathrm{F}$ & - & 2 & 3 & 37 & 8 & \multirow[t]{2}{*}{4.02} & \multirow[t]{2}{*}{0.62} & \multirow[t]{2}{*}{65.68} & \multirow[t]{2}{*}{$0.0^{*}$} & \multirow[t]{2}{*}{ A } & \multirow[t]{2}{*}{1} \\
\hline & & $\%$ & - & 4.0 & 6.0 & 74.0 & 16.0 & & & & & & \\
\hline \multirow[t]{2}{*}{2} & \multirow{2}{*}{$\begin{array}{c}\text { The text book } \\
\text { focuses on the use } \\
\text { of language. }\end{array}$} & $\mathrm{F}$ & - & 10 & 7 & 28 & 5 & \multirow[t]{2}{*}{3.56} & \multirow[t]{2}{*}{0.93} & \multirow[t]{2}{*}{26.64} & \multirow[t]{2}{*}{$0.0 *$} & \multirow[t]{2}{*}{ A } & \multirow[t]{2}{*}{3} \\
\hline & & $\%$ & - & 20.0 & 14.0 & 56.0 & 10.0 & & & & & & \\
\hline \multirow[t]{2}{*}{3} & \multirow{2}{*}{$\begin{array}{l}\text { The language used } \\
\text { is suitable for the } \\
\text { students' level. }\end{array}$} & $\mathrm{F}$ & - & 15 & 8 & 22 & 5 & \multirow[t]{2}{*}{3.34} & \multirow[t]{2}{*}{1.02} & \multirow[t]{2}{*}{13.84} & \multirow[t]{2}{*}{$0.003 *$} & \multirow[t]{2}{*}{$\mathrm{N}$} & \multirow[t]{2}{*}{4} \\
\hline & & $\%$ & - & 30.0 & 16.0 & 44.0 & 10.0 & & & & & & \\
\hline \multirow[t]{3}{*}{4} & \multirow{3}{*}{$\begin{array}{l}\text { The language in the } \\
\text { text book is easy } \\
\text { for learners to } \\
\text { understand. }\end{array}$} & $\mathrm{F}$ & - & 11 & 4 & 25 & 10 & \multirow[t]{2}{*}{3.68} & \multirow[t]{2}{*}{1.04} & 18.96 & $0.0 *$ & A & 2 \\
\hline & & $\%$ & - & 22.0 & 8.0 & 50.0 & 20.0 & & & & & & \\
\hline & & & $\mathrm{Ov}$ & all perforn & nce & & & 3.65 & 0.90 & & Agr & & \\
\hline
\end{tabular}

* Means statistically significant at the level of significance $(0.05=\alpha)$.

Notes from the results table (3) earlier mentioned that the values of Means of the items of the third branch ranged between $(3.34$ - 4.02), while the values of standard deviations ranged between $(0.62-1.04)$.

Notes from the results presented by the table (3) that all the chi - square values for all the items have been statistically significant at the level of $(\alpha=0.05)$. Which illustrates the contrast the views of the members of the study sample on these items. This means that the true observation does not correspond with the expected observation.

The following order of the items of the third branch arranged from high to low, as follows:

1. The first rank of item (1), which states: The language used in the text book is realistic, with mean (4.02), standard deviation (0.62), and agree of appreciation.

2. The second rank of item (4), which states: The language in the text book is easy for learners to understand, with mean (3.68), standard deviation (1.04), and agree of appreciation.

3. The third rank of item (2), which states: The text book focuses on the use of language, with mean (3.80), standard deviation (0.93), and agree of appreciation.

4. The fourth rank of item (3), which states: The language used is suitable for the students' level, with mean (3.34), standard deviation (1.02), and neutral of appreciation.

The means for Overall performance (3.65) with a standard deviation (0.90), and agree of appreciation.

Table No. (4) shows the values of the frequencies, percentages, averages, standard deviations, estimates and ranks responses of study sample items: Language Skills.

Table 4. Student responses to paragraphs related to the field: Language Skills

\begin{tabular}{|c|c|c|c|c|c|c|c|c|c|c|c|c|c|}
\hline \multirow[t]{2}{*}{ \# } & \multirow[t]{2}{*}{ Paragraphs } & & \multicolumn{5}{|c|}{ Responses } & \multirow[t]{2}{*}{ Means } & \multirow[t]{2}{*}{ Std. } & \multirow{2}{*}{$\begin{array}{l}\text { Chi - } \\
\text { Square }\end{array}$} & \multirow[t]{2}{*}{ Sig. } & \multirow[t]{2}{*}{ Rate } & \multirow[t]{2}{*}{ Rank } \\
\hline & & & $\begin{array}{l}\text { Strongly } \\
\text { disagree }\end{array}$ & Disagree & $\begin{array}{l}\text { Neither agree } \\
\text { nor disagree }\end{array}$ & Agree & $\begin{array}{c}\text { Strongly } \\
\text { agree }\end{array}$ & & & & & & \\
\hline \multirow[t]{2}{*}{1} & \multirow{2}{*}{$\begin{array}{l}\text { The four language } \\
\text { skills are covered } \\
\text { in the text book. }\end{array}$} & $\mathrm{F}$ & - & 3 & 7 & 30 & 10 & \multirow[t]{2}{*}{3.94} & \multirow[t]{2}{*}{0.77} & \multirow[t]{2}{*}{34.64} & \multirow[t]{2}{*}{$0.0 *$} & \multirow[t]{2}{*}{ A } & \multirow[t]{2}{*}{1} \\
\hline & & $\%$ & - & 6.0 & 14.0 & 60.0 & 20.0 & & & & & & \\
\hline \multirow[t]{2}{*}{2} & \multirow[b]{2}{*}{$\begin{array}{l}\text { The content of the } \\
\text { book develops } \\
\text { higher skills such } \\
\text { as creative } \\
\text { thinking and } \\
\text { problem-solving. }\end{array}$} & $\mathrm{F}$ & 1 & 10 & 10 & 23 & 6 & \multirow[t]{2}{*}{3.46} & \multirow[t]{2}{*}{1.01} & \multirow[t]{2}{*}{26.60} & \multirow[t]{2}{*}{$0.0 *$} & \multirow[t]{2}{*}{ A } & \multirow[t]{2}{*}{3} \\
\hline & & $\%$ & 2.0 & 20.0 & 20.0 & 46.0 & 12.0 & & & & & & \\
\hline
\end{tabular}

\begin{tabular}{|c|c|c|c|c|c|c|c|c|c|c|c|c|}
\hline \multirow{2}{*}{$\begin{array}{l}\text { The text book } \\
\text { activities provide } \\
\text { (authentic) real } \\
\text { life situations. }\end{array}$} & $\mathrm{F}$ & - & 8 & 8 & 25 & 9 & \multirow[t]{2}{*}{3.70} & \multirow{2}{*}{0.95} & \multirow{2}{*}{16.72} & \multirow{2}{*}{$0.001 *$} & \multirow{2}{*}{ A } & \multirow[t]{2}{*}{2} \\
\hline & $\%$ & - & 16.0 & 16.0 & 50.0 & 18.0 & & & & & & \\
\hline
\end{tabular}

* Means statistically significant at the level of significance $(0.05=\alpha)$. 
Notes from the results table (4) earlier mentioned that the values of Means of the items of the fourth branch ranged between $(3.46$ - 3.94), while the values of standard deviations ranged between $(0.77-1.01)$.

Notes from the results presented by the table (4) that all the chi - square values for all the items have been statistically significant at the level of $(\alpha=0.05)$. Which illustrates the contrast the views of the members of the study sample on these items. This means that the true observation does not correspond with the expected observation.

The following order of the items of the fourth branch arranged from high to low, as follows:

1. The first rank of item (1), which states: The four language skills are covered in the text book., with mean (3.94), standard deviation (0.77), and agree of appreciation.

2. The second rank of item (3), which states: The text book activities provide (authentic) real life situations, with mean (3.70), standard deviation (0.95), and agree of appreciation.

3. The third rank of item (2), which states: The content of the book develops higher skills such as creative thinking and problem-solving., with mean (3.46), standard deviation (1.01), and agree of appreciation.

The means for Overall performance (3.70) with a standard deviation (0.91), and agree of appreciation.

Table No. (5) shows the values of the frequencies, percentages, averages, standard deviations, estimates and ranks responses of study sample items: Technical Aspect.

Table 5. Student responses to paragraphs related to the field: Technical Aspect

\begin{tabular}{|c|c|c|c|c|c|c|c|c|c|c|c|c|c|}
\hline \multirow[t]{2}{*}{ \# } & \multirow[t]{2}{*}{ Paragraphs } & & \multicolumn{5}{|c|}{ Responses } & \multirow[t]{2}{*}{ Means } & \multirow[t]{2}{*}{ Std. } & \multirow{2}{*}{$\begin{array}{c}\text { Chi - } \\
\text { Square }\end{array}$} & \multirow[t]{2}{*}{ Sig. } & \multirow[t]{2}{*}{ Rate } & \multirow[t]{2}{*}{ Rank } \\
\hline & & & $\begin{array}{l}\text { Strongly } \\
\text { disagree }\end{array}$ & Disagree & $\begin{array}{l}\text { Neither } \\
\text { agree } \\
\text { nor } \\
\text { disagree }\end{array}$ & Agree & $\begin{array}{c}\text { Strongly } \\
\text { agree }\end{array}$ & & & & & & \\
\hline \multirow[t]{2}{*}{1} & \multirow{2}{*}{$\begin{array}{c}\text { The headlines } \\
\text { and sub-titles } \\
\text { are organized } \\
\text { well. }\end{array}$} & $\mathrm{F}$ & - & 3 & 6 & 24 & 17 & 4.10 & 0.84 & 22.80 & $0.0^{*}$ & A & 2 \\
\hline & & $\%$ & - & 6.0 & 12.0 & 48.0 & 34.0 & & & & & & \\
\hline \multirow[t]{2}{*}{2} & \multirow{2}{*}{$\begin{array}{c}\text { The units are } \\
\text { organized } \\
\text { well and } \\
\text { show } \\
\text { sequence. }\end{array}$} & $\mathrm{F}$ & - & 6 & 5 & 26 & 13 & 3.92 & 0.92 & 22.48 & $0.0^{*}$ & A & 5 \\
\hline & & $\%$ & - & 12.0 & 10.0 & 52.0 & 26.0 & & & & & & \\
\hline \multirow[t]{2}{*}{3} & \multirow[b]{2}{*}{$\begin{array}{l}\text { The book } \\
\text { contains } \\
\text { pictures and } \\
\text { schedules } \\
\text { which help } \\
\text { Students to } \\
\text { understand } \\
\text { written texts. }\end{array}$} & $\mathrm{F}$ & - & 4 & 5 & 27 & 14 & 4.02 & 0.84 & 27.28 & $0.0^{*}$ & A & 3 \\
\hline & & $\%$ & - & 8.0 & 10.0 & 54.0 & 28.0 & & & & & & \\
\hline \multirow[t]{2}{*}{4} & \multirow{2}{*}{$\begin{array}{c}\text { Text book } \\
\text { Instructions } \\
\text { are written in } \\
\text { simple and } \\
\text { clear } \\
\text { language. }\end{array}$} & $\mathrm{F}$ & - & 4 & 3 & 34 & 9 & 3.96 & 0.75 & 50.96 & $0.0 *$ & A & 4 \\
\hline & & $\%$ & - & 8.0 & 6.0 & 68.0 & 18.0 & & & & & & \\
\hline \multirow[t]{2}{*}{5} & \multirow{2}{*}{$\begin{array}{c}\text { Text book } \\
\text { appearance is } \\
\text { attractive and } \\
\text { nice. }\end{array}$} & $\mathrm{F}$ & - & 8 & 7 & 17 & 18 & 3.90 & 1.07 & 8.08 & $0.04 *$ & $\mathrm{~A}$ & 6 \\
\hline & & $\%$ & - & 16.0 & 14.0 & 34.0 & 36.0 & & & & & & \\
\hline \multirow[t]{3}{*}{6} & \multirow{2}{*}{$\begin{array}{l}\text { The text book } \\
\text { has a high } \\
\text { quality of } \\
\text { printing. }\end{array}$} & F & - & 4 & 1 & 23 & 22 & 4.26 & 0.85 & 32.40 & $0.0^{*}$ & SA & 1 \\
\hline & & $\%$ & - & 8.0 & 2.0 & 46.0 & 44.0 & & & & & & \\
\hline & \multicolumn{7}{|c|}{ Overall performance } & 4.03 & 1.07 & & & & \\
\hline
\end{tabular}

* Means statistically significant at the level of significance $(0.05=\alpha)$. 
Notes from the results table (5) earlier mentioned that the values of Means of the items of the fifth branch ranged between $(3.90$ - 4.26), while the values of standard deviations ranged between $(0.75-1.07)$.

Notes from the results presented by the table (5) that all the chi - square values for all the items have been statistically significant at the level of $(\alpha=0.05)$. Which illustrates the contrast the views of the members of the study sample on these items. This means that the true observation does not correspond with the expected observation.

The following order of the items of the fifth branch arranged from high to low, as follows:

1. The first rank of item (6), which states: The text book has a high quality of printing, with mean (4.26), standard deviation (0.85), and strong agree of appreciation.

2. The second rank of item (1), which states: The headlines and sub-titles are organized well., with mean (4.10), standard deviation (0.84), and agree of appreciation.

3. The third rank of item (3), which states: The book contains pictures and schedules which help Students to understand written texts., with mean (4.02), standard deviation (0.84), and agree of appreciation.

4. The fourth rank of item (4), which states: Text book Instructions are written in simple and clear language, with mean (3.96), standard deviation (0.75), and agree of appreciation.

5. The fifth rank of item (2), which states: The units are organized well and show sequence, with mean (3.92), standard deviation (0.92), and agree of appreciation.

6. The sixth rank of item (5), which states: Text book appearance is attractive and nice, with mean (3.90), standard deviation (1.07), and agree of appreciation.

The means for Overall performance (4.03) with a standard deviation (1.07), and agree of appreciation.

\section{Conclusion}

This chapter consists of four sections: summary, conclusion, recommendations and suggestions. First, the summary presents an overall account for all parts of the research. Second, the conclusion presents the study's findings in light of the researcher's hypotheses. Third, it provides recommendations for modifying the textbook at hand and finally, it ends with suggestions for future research.

\subsection{Summary of the Study}

The purpose of this study was to evaluate the quality of the Second Intermediate Grade English Language Textbook for Saudi girls' Schools "Say It In English "from the teachers' point of view. The research is concentrated on answering the following research questions:

- What are the strengths in the Intermediate Saudi English language text book in CB objectives, content, language style, skills and technical aspects and appearance of the $\mathrm{CB}$ from the teachers' point of view?

- What are the weaknesses in the Intermediate Saudi English language text book in CB objectives, content, language style, skills and technical aspect and appearance of the CB from the teachers' point of view?

A survey questionnaire was used in this study to elicit the perspectives about the textbook from 50 English language female teachers in Riyadh Educational Zone. The questionnaire consisted of 23 items grouped under 5 main categories: objectives, content, language style, language skills and technical aspect of the CB. The data were subjected to analysis through descriptive statistics.

To achieve the objectives of the study, the researcher prepared a questionnaire to assess the dimensions of the English text book of second intermediate grade in SA. The teachers' responses to the questionnaire statements were collected and analyzed in terms of frequency and percentage of responses. The researcher used the program Statistical Package for Social Sciences in analyzing data.

The findings of this research study revealed important points related to the characteristics of a good textbook. The findings were generally in favour of the textbook except for the language style and some other sub-items. Out of 23 items in the questionnaire, only 4 items had arithmetic means less than 3.50 (the average). The category that had the highest mean was the one on technical aspects, while the category that had the lowest mean was the one on language style.

\subsection{Conclusion and Discussion}

Based on the results obtained from the statistical analysis, the following conclusions are drawn:

1. It satisfies teachers' expectations regarding the objectives covered. In addition, objectives are clear, realistic, suitable to the students' level and accurate to be applied. Also, objectives can be achieved within the specific, limited time. According to a very high percentage of the participants, all the objectives are covered, presented and graded in a satisfactory manner.

2. It satisfies teachers' expectations regarding the content that is appropriate with the principles of Islam and our culture. However, the textbook failed to express positive views of the topics of the content that meet the students' needs according to almost half of the participants.

3. It satisfies teachers' expectations regarding the languages content as it covers all language skills. However, the content regarding its suitability for the students' cognitive, affective and psychomotor level, does not satisfy the participants' expectations. 
4. It satisfies teachers' expectations regarding the activities content as it includes authentic real-life situations.

5. It satisfies teachers' expectations regarding a content that is free from grammatical errors.

6. It satisfies teachers' expectations regarding the language used in as much as it is realistic. However, according to the majority of the participants, the language style is not suitable for the students' level.

7. It satisfies teachers' expectations regarding the focus on the use of language. In addition, the language is easy for learners to understand.

8. It satisfies teachers' expectations regarding language skills. Four language skills are covered and the content of the book develops higher skills such as creative thinking and problem-solving. In addition, its activities provide (authentic) real life situations.

9. It satisfies teachers' expectations regarding its technical aspect. However, an appropriate glossary should be added.

10. It satisfies teachers' expectations regarding its high quality of printing and its attractive appearance. However, the units must be better organized to show a sequence that can stimulate students' creativity.

11. It satisfies teachers' expectations regarding its pictures and schedules which help students to understand written texts.

12. It satisfies teachers' expectations regarding the headings and sub-titles which are organized well.

13. It satisfies teachers' expectations regarding the instructions that are written in a simple and clear language. However, more illustrations that can stimulate students' critical thinking are required.

\subsection{Recommendations}

Based on the results obtained from this study, the following points are recommended:

Compose topics that can provoke students' critical thinking, encourage them to create their ideas and generate higher thinking.

$>$ Insert a context that can express positive views of ethnic origins, occupations, age groups, social groups and disability.

$>$ Add an appropriate glossary at the end of the textbook for the benefit of both teachers and students.

$>$ Urge students to acquire a simplified monolingual dictionary (e.g. Frisby's Longman's Pocket English Dictionary) and/or a bilingual pocket dictionary (e.g.Balabki's Almawrid Alqareeb). Longman's Pocket English Dictionary contains illustrations and simplified definitions of words. Students will be motivated to use the dictionary since this will be their first experience in dictionary use.

$>$ Replace the listening material with a better one that is well recorded, more authentic and accompanied with background information, questions and activities.

$>$ Allow some flexibility through practicing language freely, formally and informally so students can practice various degrees of language such as giving directions, greetings, short telephone exchanges, polite requests and formal invitations.

$>$ Include information about the inner lives of the characters used in the book as this can allow students to discuss the characters' personalities, behaviors, problems, attitudes and ways of thinking. In addition, these characters can be examples for the students in their real lives.

$>$ It was clear from the research results that the textbook fails to satisfy the teachers' expectations regarding the suitability of the language used at the students' level. These language and learning styles should be updated and student-centered approaches should be used to engage students affectively through excitement, fun and emotion. Communicative approaches that can allow various activities are highly recommended to encourage students to use language effectively.

$>$ Vary learning and language styles. The textbook emphasizes analytical learning that depends mainly on practice and memorization and does not take into account the fact that some students may prefer an experiential learning style.

$>$ Add communicative exercises and activities such as group and pair work, games, puzzles and role play, as these can help students carry out their communicative tasks in real life.

$>$ Encourage students to make PowerPoint presentations, which contain animated pictures of the CB's content.

5.4 Suggestions for Further Studies

$\checkmark$ An extension of this study is required to evaluate the English language textbooks recently introduced at the Saudi intermediate schools.

$\checkmark$ A content analysis study for the same textbook evaluated in this study is needed as it may uncover more valuable results.

$\checkmark$ A further study might be conducted to investigate the whole program for teaching English as a foreign language in Saudi Arabia.

$\checkmark \quad$ Empirical evaluative studies to evaluate the English textbooks in Saudi girls' schools are also suggested.

$\checkmark$ Finally, the recommendations given here will be worth the work done by students, teachers, supervisors and the researcher if they help to improve current and future language learning success of Saudi pupils. 


\section{References}

Alamri, A. (2008). An Evaluation of the Sixth Grade English Language Textbook for Saudi Boys' Schools. Thesis Submitted to the Department of English Language in Partial Fulfilment of the Requirements for the Master Degree of Arts in Applied Linguistics at the College of Arts at King Saud University.

Al-Hajailan, T. (2003). Teaching English in Saudi Arabia. Riyadh: Aldar Alsawtia for Publishing and Distribution.

Al-Jaser, A. M. (1989). An analysis of the English language textbooks taught at the first year boy and girls' secondary schools: a comparative study. Unpublished MA dissertation, King Saud University, Riyadh.

Al-Mofarreh, et al. (2005) English for Saudi Arabia: Sixth Grade Elementary. Riyadh: Ministry of Education.

Al-Sadan, I. A. (2000) Educational assessment in Saudi Arabian schools. Unpublished PhD thesis, Cardiff University.

Al-Subahi, A. A. O. (1989) A Communicative-Functional English Curriculum For Intermediate School in Saudi Arabia: a model for English syllabus design and implementation. Unpublished PhD thesis, Department of Education, University of Edinburgh.

Al-Saif, A. (2005). An evaluation of the TEFL textbook for the 6th elementary class in Saudi Arabia. Unpublished MA thesis, 78 pages. Essex University, UK.

Al-Sowat, H. (2012), An evaluation of English language Textbook "say it in English" for first year Intermediate Grade in Saudi Arabia. Journal of studies in curriculum and supervision, 3(2).

Alshumaimeri, Y (2001), Saudi Students' Perceptions of Their Textbook: English for Saudi Arabia, (EFSA), Secondary Year One : Needs Analysis.

Al-Yousef, H.S. (2007). An evaluation of the third grade intermediate English textbook in Saudi Arabia. Retrieved: December 2012. $1, \quad$ From the World Wide http://repository.ksu.edu.sa/jspui/bitstream/123456789/8767/1/An $\% 20$ evaluation $\% 20$ of $\% 20$ the $\% 20$ third $\% 20$ grade $\% 20 \mathrm{i}$ ntermediate.pdf

Anderson, R.D. (1995). Curriculum Reforms. Dilemmas and Promise. Phi Delta Kappan 77 (1), 33-36.

Chambers, F. (1997). Seeking consensus in textbook evaluation. ELT Journal. 51(1).

Chambliss, M.J. (1994). Evaluating the quality of textbooks for diverse learners. Remedial and Special Education, 15, 348-362.

Cowling, J. (2007). Needs analysis: Planning a syllabus for a series of intensive workplace courses at a leading Japanese company. English for Specific Purposes 26, 426-442.

Cunningsworth, A. (1984). Evaluating and selecting EFL teaching materials. Oxford: Heinemann Educational.

Cunningsworth, A. (1995). Choosing Your Course Book, Max Hueber Verlag.

Ellis, R. (1997). The empirical evaluation of teaching materials. ELT Journal, 51(1), 36-42.

Eliss , R. (2005), Principles of instructed Language Learning. System 33, 209-224.[1,4]

Ereksoussy, M. (1993). Evaluating the English language textbook studied in the first year at girls' intermediate schools in Saudi Arabia. Unpublished MA dissertation, King Saud University, Riyadh.

Flutter, J. (2007). Teacher development and pupil voice. The Curriculum Journal 18, no. 3: 343-54.

Fullan, M., Miles, M.B. (1992). Getting reform right: what works and what doesn't. Phi Delta Kappan 73 (10), $744-$ 752.

Gamoran, A. (1997). Curriculum change as a reform strategy: lessons from the United States and Scotland. Teacher College Records 98(4), 608-628.

Garinger, D. (2001). Textbook evaluation. TEFL Web Journal. Retrieved from: http://www.teflwebj.org/v1n1/garinger.html

Habtoor, H.A. (2012). English for Specific Purpose Textbook in EFL Milieu: An Instructor's Perspective Evaluation. International Journal of Linguistics, 4(3).

Hutchinson, T., \& Torres, E. (1994). The textbook as agent of change. ELT Journal, 48(4), 315-328.

Jackson, J. (2005). An Inter-university, Cross-disciplinary Analysis of Business Education: Perceptions of Business Faculty in Hong Kong. English for Specific Purposes, 24(3), 293-306.

Khafaji, A. (2004). An evaluation of the materials used for teaching English to the second secondary level in male public high school in Saudi Arabia. Unpublished MA thesis, University of Exeter. Exeter, UK.

Kirkgöz, Y. (2009). Evaluating the English Text Books for Young Learners of English at Turkish Primary Education. Procedia Social and Behavioral Sciences 1, 79-83.

Klein, M.F. (1994). The toll for curriculum reforms. Peabody Journal of Education 69(3), 19-34.

Mabdkhali, H. (2005). A language curriculum model: A case study in Saudi Arabia. Unpublished doctoral dissertation. Ball State University, Muncie Indiana. Retrieved January 22, 2006, from http://www.bsu.edu/libraries/virtualpress/student/dissertations/pdfs/M33 2005MadkhaliHusamM.html McGrath, I. (2002). Materials Evaluation and Design for Language Teaching. Edinburgh: Edinburgh University Press Mehrdad, A. (2012). A subjective needs assessment of EGP students. Social and Behavioral Sciences. 31,546 - 554. Mertens, D.M. (2005). Research and evaluation in education and psychology. 2nd Edition. California: Sage Publications Inc.

O’Neill, R. (2008). Why use textbooks? ELT Journal, 36, 2, 104-111.

Ranalli,J ,M. (2002), Comaring Scoring Procedures on a Cloze Test, Retrieved on Nov. 23.2005: http/ www.cels.bham.ac.uk/ recourses /essays / Ranalli5.pdf

Richards, J. C. (2011). Curriculum development in language teaching. Cambridge: Cambridge University Press.

Sheldon, L.E. (1988). Evaluating ELT textbooks and materials. ELT Journal, 42(4), 237-246. 
Skierso, A. (1991), Text Book Selection and Evaluation, In M Celce-Murcia (Ed) Teaching English as a Second or Foreign Language (pp.432-453). Boston: Heinle and Heinle.

Thein, N. (2006) Evaluating the suitability and effectiveness of three English course books at Myanmar Institute of Technology. Unpublished MA thesis, University of Thailand. Thailand.

Williams, P., M.Williams, C. Guray, A. Bertram, R. Brenton, and A. McCormack. (1994). Perceived barriers to implementing a new integrated curriculum. Curriculum Perspectives, 14(1), 17-23.

Zarei, G. \& Khalessi, M. (2011). Cultural load in English language textbooks: an analysis of interchange series.

Procedia Social and Behavioral Sciences 15, 294-301.

\section{Appendix}

$\begin{array}{lllll}\text { No Dimensions And Subtitles } & \begin{array}{l}\text { Strongly } \\ \text { agree }\end{array} & \begin{array}{l}\text { Agree } \\ \text { Neither } \\ \text { agree nor } \\ \text { disagree }\end{array} & \begin{array}{l}\text { Disagree } \\ \text { disagree } \\ \text { dislongly }\end{array}\end{array}$

\section{Objectives}

1 Textbook objectives are clear and accurate to be applied.

2 Objectives are realistic.

3 Objectives of the material are suitable for students' level.

4 Objectives can be achieved within the specific time that has been limited.

\section{Content}

1 The content of the book is appropriate with the principles of Islam and our culture.

2 The content of the book covers all language skills.

3 The topics of the content meet the students' needs.

4 The content of the book includes authentic real-life situations.

5 The content of the book is suitable for the students' cognitive, affective and psychomotor level.

6 The content is free from grammatical errors

Language Style

1 The language used in the text book is realistic.

2 The text book focuses on the use of language.

3 The language used is suitable for the students' level.

4 The language in the text book is easy for learners to understand.

\section{Language Skills}

1 The four language skills are covered in the text book

2 The content of the book develops higher skills such as creative thinking and problem-solving.

3 The text book activities provide (authentic) real life situations.

Technical Aspect

1 The headlines and sub-titles are organized well.

2 The units are organized well and show sequence.

3 The book contains pictures and schedules which help Students to understand written texts.

$4 \quad$ Text book Instructions are written in simple and clear language.

5 Text book appearance is attractive and nice.

6 The text book has a high quality of printing. 